\title{
LEAD POISONING IN CHILDREN
}

\author{
BY
}

\author{
A. A. MONCRIEFF, O. P. KOUMIDES, BARBARA E. ClAYTON, A. D. PATRICK, \\ A. G. C. RENWICK and G. E. ROBERTS \\ From the Department of Chemical Pathology, The Hospital for Sick Children, and the Institute of Child Health, \\ Great Ormond Street, London
}

(RECEIVED FOR PUBLICATION AUGUST 2, 1963)

Byers (1959) has recently reviewed lead poisoning in children and stressed its importance as a disease in childhood. In 1950, Clark commented on the fact that the condition was well recognized and apparently common in the United States though comparatively rare or usually unrecognized in Great Britain. From the experience of American workers such as McLaughlin (1956) and Jacobziner and Raybin (1962), it seems likely that many patients are missed because (1) the presenting symptoms are frequently non-specific and extremely variable, (2) facilities for the determination of lead in blood are not readily available, (3) the usually accepted laboratory criteria of lead poisoning such as punctate basophilia and increased urinary coproporphyrins are frequently absent in milder cases, and (4) there is some doubt about the normal range for the level of lead in blood, and the values indicative of lead poisoning.

Levels of lead in the blood of normal children have been determined by a number of workers (for a review see Byers, 1959), and the upper limit of normal has usually been fixed at 50 to $60 \mu \mathrm{g}$./ $100 \mathrm{ml}$. blood, e.g. $60 \mu \mathrm{g} . / 100 \mathrm{ml}$. by Chisolm and Harrison (1957) and $50 \mu \mathrm{g} . / 100 \mathrm{ml}$. by Bradley, Powell, Niermann, McGrady and Kaplan (1956). Byers (1959) has drawn attention to the fact that from a study of the published material it should be concluded that the actual level at which poisoning occurs is variable. Of the patients discussed by Bradley et al. (1956), eight children had blood lead levels between 50 and $80 \mu \mathrm{g} . / 100 \mathrm{ml}$., and were asymptomatic. They were later admitted to hospital with lead encephalopathy, and the mean blood lead was only $43 \mu \mathrm{g} . / 100 \mathrm{ml}$.

The deleterious effect of lead poisoning on the growth and development of the nervous system of the young child was studied by Byers and Lord (1943). They followed up 20 children eight years after they had been in hospital with lead poisoning. The age at the time of the original admission varied from 10 months to 6 years and 9 months, and in the majority of patients lead had been obtained by chewing paint on cots and window-sills. All the patients showed bands of increased density at the ends of their long bones and had some other features characteristic of lead poisoning. Though none of them had acute encephalopathy and, though they were all considered to have made a complete recovery by the time of discharge from hospital, eight years later only one was making satisfactory progress at school and most of them had evidence of intellectual and emotional difficulties.

The present study was undertaken primarily to see whether any children being referred to The Hospital for Sick Children, Great Ormond Street, for the investigation of mental retardation had lead poisoning. As the method for the determination of blood lead became more freely available it was also performed more frequently in children who had pica, anaemia, abdominal pain and unexplained vomiting, and children in whom a preliminary diagnosis of 'encephalitis' was made by the consultant physician. An essential preliminary was the determination of the normal range for blood lead in children.

Since there is such individual variation in the level of blood lead at which poisoning occurs, some other means of determining whether a lead level was toxic was sought. Blood pyruvate levels following glucose were determined in a number of patients, since thiol groups which are essential for pyruvate oxidation may be inactivated by lead.

Some studies on the effect of treatment on clinical progress, the levels of lead and pyruvate in blood, and urinary lead excretion are also reported in this paper.

\section{Concentration of Lead in the Blood}

Normal Children. Blood lead was determined in 80 children between the ages of 4 months and $14 \frac{1}{4}$ 
TABLE 1

DETAILS OF 20 CHILDREN

\begin{tabular}{|c|c|c|c|c|c|c|c|}
\hline $\begin{array}{l}\text { Patient } \\
\text { No. }\end{array}$ & Sex & $\begin{array}{c}\text { Age (yrs.) } \\
\text { When Blood } \\
\text { Lead First } \\
\text { Estimated }\end{array}$ & $\begin{array}{l}\text { Ethnic } \\
\text { Origin }\end{array}$ & $\begin{array}{l}\text { Presenting } \\
\text { Symptoms }\end{array}$ & $\begin{array}{l}\text { Duration of } \\
\text { Symptoms }\end{array}$ & Pica & $\begin{array}{l}\text { Intelligence } \\
\text { Before Illness }\end{array}$ \\
\hline $1^{*}$ & $\mathbf{M}$ & 5 & Italian Greek & $\begin{array}{l}\text { Vomiting, abdominal pain (lead } \\
\text { estimated because of behaviour } \\
\text { disturbance) }\end{array}$ & 2 yrs. & + & Normal \\
\hline $2 *$ & $\mathbf{F}$ & $2 \frac{8}{12}$ & Caucasian & $\begin{array}{l}\text { Psychotic with increasing be- } \\
\text { haviour problems }\end{array}$ & $1 \mathrm{yr}$. & + & Retarded \\
\hline $3^{*}$ & $\mathbf{F}$ & $2 \frac{8}{12}$ & , & $\begin{array}{l}\text { Backward child; slow progress } \\
\text { ceased entirely }\end{array}$ & $\begin{array}{l}\text { Always backward, no } \\
\text { progress for } 3-4 \text { mths. }\end{array}$ & + & Retarded \\
\hline 4 & $\mathbf{M}$ & $1_{12}^{8}$ & , & General irritability; vomiting & 3 mths. & + & Normal \\
\hline 5 & $\mathbf{M}$ & 4 & West Indian & Asymptomatic & No symptoms & + & , \\
\hline 6 & $\mathbf{M}$ & $4_{12}^{3}$ & Caucasian & Unsteadiness, headaches, vomiting & 3 wks. & - & " \\
\hline 7 & $\mathbf{F}$ & $1 \frac{1}{2}$ & " & Asymptomatic & No symptoms & - &. \\
\hline 8 & $\mathbf{M}$ & 3 & , & General malaise, vomiting & 3 wks. & + & $"$ \\
\hline $9 *$ & $\mathbf{M}$ & $2 \frac{\beta}{12}$ & " & $\begin{array}{l}\text { Failure to thrive, vomiting, mental } \\
\text { retardation }\end{array}$ & $3 \mathrm{mths}$. & + & , \\
\hline 10 & $\mathbf{F}$ & $1 \frac{9}{12}$ & $\begin{array}{l}\text { Caucasian } \\
\text { West Indian }\end{array}$ & Failure to thrive, loss of weight & 15 mths. & + & $"$ \\
\hline 11 & $\mathbf{M}$ & $1_{12}^{6}$ & $\begin{array}{l}\text { Caucasian } \\
\text { West Indian }\end{array}$ & Anorexia, loss of weight. vomiting & $1 \mathrm{mth}$. & + & , \\
\hline $12^{*}$ & $\mathbf{M}$ & 3 & Caucasian & $\begin{array}{l}\text { Anorexia, irritability (lead esti- } \\
\text { mated because of behaviour } \\
\text { disorder) }\end{array}$ & 6 mths. & + & " \\
\hline 13 & $\mathbf{M}$ & 3 & West Indian & Listlessness, weight loss & 3 mths. & + & \\
\hline 14 & $\mathbf{M}$ & $\frac{9}{12}$ & Caucasian & Vomiting, irritability, weight loss & 5 wks. & + & " \\
\hline 15 & $\mathbf{M}$ & $2 \frac{8}{12}$ & Indian & Vomiting, irritability & 4 wks. & + & $"$ \\
\hline 16 & $\mathbf{F}$ & $1 \frac{7}{12}$ & Caucasian & Anorexia, vomiting, loose stools & $1 \mathrm{mth}$. & + & \\
\hline $17^{*}$ & $\mathbf{F}$ & $3 \frac{9}{12}$ & , & Delayed speech and 'fits' & $\begin{array}{l}\text { 'Fits' for } 18 \text { mths., never } \\
\text { spoken sentences }\end{array}$ & + & \\
\hline 18 & F & $\frac{9}{12}$ & Indian & Anorexia, vomiting, pallor & $1 \mathrm{mth}$. & Not known & , \\
\hline $19^{*}$ & $\mathbf{M}$ & 3 & Caucasian & Mental deterioration beginning & $2 \frac{1}{2}$ yrs. & - & Presumed normal \\
\hline $20 *$ & $\mathbf{M}$ & $1 \frac{8}{12}$ & , $\}$ & after weaning at 6 months & $1 \mathrm{yr}$. & - & ", \\
\hline
\end{tabular}

* Included in Fig 2.

$+=$ Positive. $\quad-=$ Negative

A gap indicates that an investigation was not performed.

years. These children were not mentally retarded and had no history of pica. The results are shown in Fig. 1. All except two had levels of $36 \mu \mathrm{g}$. or less per $100 \mathrm{ml}$. blood, and this value has been taken as the upper limit of normal. There was no sex difference. The child with a level of $42 \mu \mathrm{g}$. had eczema which had been treated with large amounts of tar paste; since there are no pharmaceutical levels for the lead content in tar, absorption of traces of lead through the broken skin over several years seemed likely to account for this slightly higher value. 


\begin{tabular}{|c|c|c|c|c|c|c|c|c|}
\hline \multirow{2}{*}{$\begin{array}{l}\text { Source of } \\
\text { Lead }\end{array}$} & \multirow{2}{*}{$\begin{array}{c}\text { Haemo- } \\
\text { globin } \\
(\%)\end{array}$} & \multirow{2}{*}{$\begin{array}{c}\text { Red Cell } \\
\text { Morphology }\end{array}$} & \multirow{2}{*}{$\begin{array}{c}\text { Punctate } \\
\text { Basophilia } \\
\text { or } \\
\text { Stippling }\end{array}$} & \multirow{2}{*}{$\begin{array}{c}\text { Excess } \\
\text { Copro- } \\
\text { porphyrins } \\
\text { in Urine }\end{array}$} & \multicolumn{2}{|c|}{$\begin{array}{l}\text { X-rays For } \\
\text { Lead }\end{array}$} & \multirow{2}{*}{$\begin{array}{c}\text { Blood } \\
\text { Lead } \\
(\mu \mathrm{g} . / 100 \mathrm{ml} .)\end{array}$} & \multirow{2}{*}{$\begin{array}{c}\text { Blood } \\
\text { Pyruvate } \\
\text { (mg./100 ml.) }\end{array}$} \\
\hline & & & & & Abdomen & Bone & & \\
\hline Dirt in yard; dustbins & 72 & Normal & Nil & Nil & - & - & 54 & $2 \cdot 39$ \\
\hline Dirt & 82 & , & Nil & Nil & - & - & 54 & $1 \cdot 35$ \\
\hline Dirt, coal, toys & 90 & ", & Nil & Nil & - & - & 48 & $1 \cdot 95$ \\
\hline Red lead in putty & 52 & $\begin{array}{l}\text { Hypochromia, } \\
\text { anisocytosis, } \\
\text { polychromasia }\end{array}$ & + & Nil & + & + & 110 & $1 \cdot 26$ \\
\hline " & 67 & Hypochromia & Nil & Nil & - & - & 62 & $0 \cdot 88$ \\
\hline $\begin{array}{l}\text { Father sprayed car at home and } \\
\text { children 'helped' }\end{array}$ & $\begin{array}{l}92 \\
79\end{array}$ & $\begin{array}{c}\text { Normal } \\
\quad,,\end{array}$ & $\begin{array}{l}\text { Nil } \\
\text { Nil }\end{array}$ & $\begin{array}{l}\text { Nil } \\
\text { Nil }\end{array}$ & - & - & $\begin{array}{c}55 \\
9 \text { mths. later, } 78 \\
\text { (no treatment) }\end{array}$ & $1 \cdot 70$ \\
\hline : & 75 & $"$ & Nil & Nil & - & - & 70 & $1 \cdot 23$ \\
\hline Dirt & 59 & $\begin{array}{l}\text { Hypochromia, } \\
\text { anisocytosis, } \\
\text { polychromasia }\end{array}$ & + & + & - & - & 101 & $1 \cdot 44$ \\
\hline $\begin{array}{l}\text { Paint chips from railings, licking } \\
\text { decorators' paint brushes }\end{array}$ & 82 & Normal & Nil & Nil & - & + & 72 & $1 \cdot 40$ \\
\hline ? Old paint & 66 & $\begin{array}{l}\text { Hypochromia, } \\
\text { polychromasia }\end{array}$ & + & Nil & - & - & 40 & $2 \cdot 71$ \\
\hline Old paint & 43 & $\begin{array}{l}\text { Hypochromia, } \\
\text { anisocytosis, } \\
\text { polychromasia }\end{array}$ & $\mathrm{Nil}$ & + & + & - & 380 & 0.92 \\
\hline Dirt & 56 & $\begin{array}{l}\text { Hypochromia, } \\
\text { anisocytosis }\end{array}$ & Nil & Nil & - & - & 64 & $1 \cdot 10$ \\
\hline Red lead in putty & 51 & $\begin{array}{l}\text { Hypochromia, } \\
\text { anisocytosis, } \\
\text { polychromasia }\end{array}$ & + & Nil & - & - & 65 & $2 \cdot 79$ \\
\hline ? Cot paint & 54 & $\begin{array}{l}\text { Hypochromia, } \\
\text { anisocytosis, } \\
\text { polychromasia }\end{array}$ & Nil & Nil & - & - & 62 & $1 \cdot 90$ \\
\hline Paint in house & 40 & $\begin{array}{l}\text { Hypochromia, } \\
\text { anisocytosis, } \\
\text { polychromasia }\end{array}$ & + & Nil & + & + & 288 & 一 \\
\hline , , , & 55 & $\begin{array}{l}\text { Hypochromia, } \\
\text { anisocytosis, } \\
\text { polychromasia }\end{array}$ & $\mathrm{Nil}$ & Nil & - & - & 102 & $2 \cdot 60$ \\
\hline ? Paint in house & 80 & Normal & Nil & Nil & - & - & 66 & $1 \cdot 95$ \\
\hline Unknown & 30 & $\begin{array}{l}\text { Hypochromasia, } \\
\text { anisocytosis }\end{array}$ & Nil & Nil & - & - & 62 & $1 \cdot 65$ \\
\hline $\begin{array}{l}\text { Home-grown vegetables from soil } \\
\text { containing old battery casings }\end{array}$ & & & & & - & - & $\begin{array}{l}56 \\
44\end{array}$ & $\begin{array}{l}1 \cdot 26 \\
1 \cdot 37\end{array}$ \\
\hline
\end{tabular}

Children with Mental Retardation or Severe Behaviour Disorders. Blood lead was determined in 122 children aged 6 months to 14 years. These patients were mentally retarded, or had defects of, for example, speech so that they superficially appeared mentally retarded, or had severe psychological dis- turbances, but otherwise were unselected except that children with gross physical abnormalities such as hydrocephalus were not included. The results shown in Fig. 2 indicate that $55(45 \%)$ of the children had levels greater than $36 \mu \mathrm{g}$. Patients $1,2,3,12,17,19$ and 20 in Table 1 are examples of this type. 


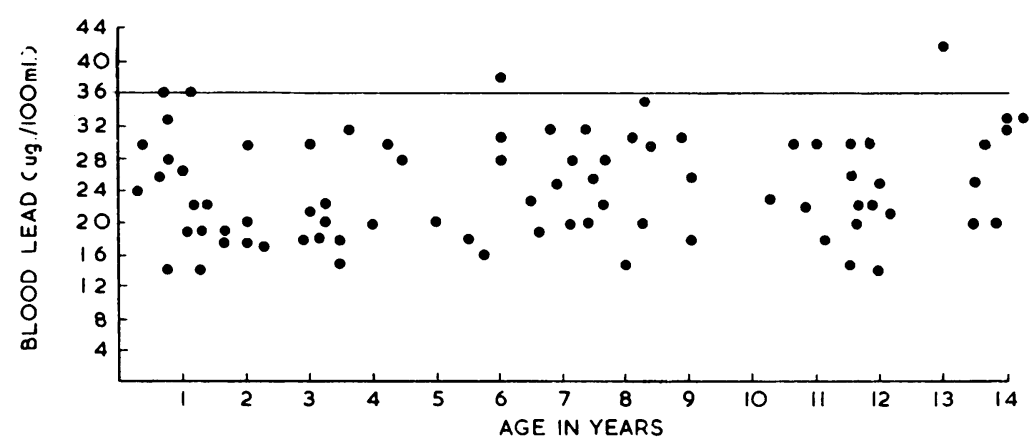

Fig. 1.-Levels of lead in the blood of normal children.

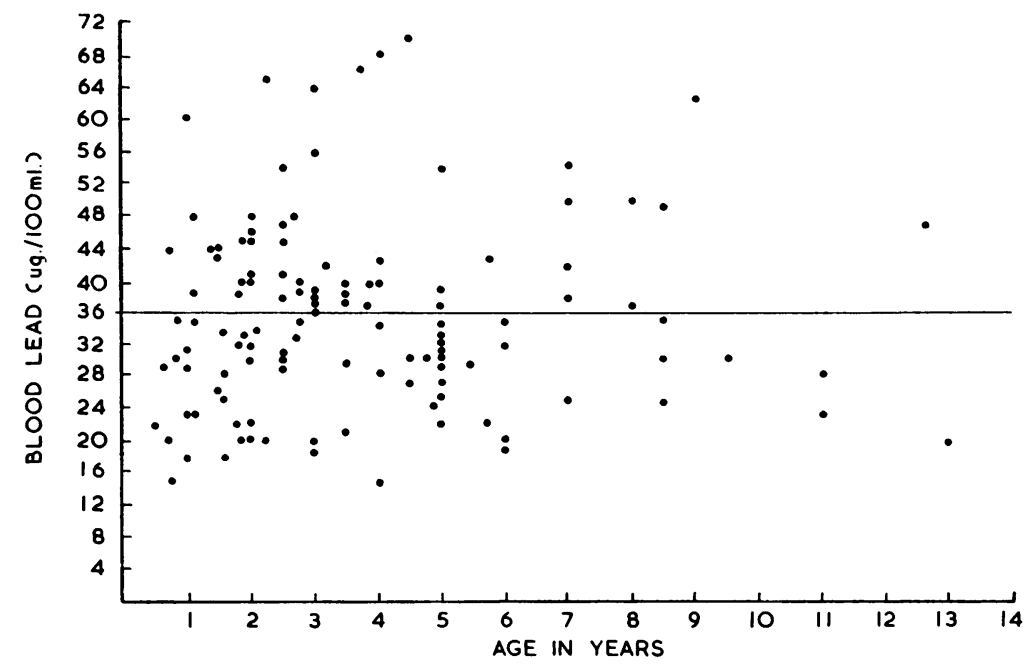

Fio. 2.-Levels of lead in the blood of children who were mentally retarded or who had severe behaviour disorders.

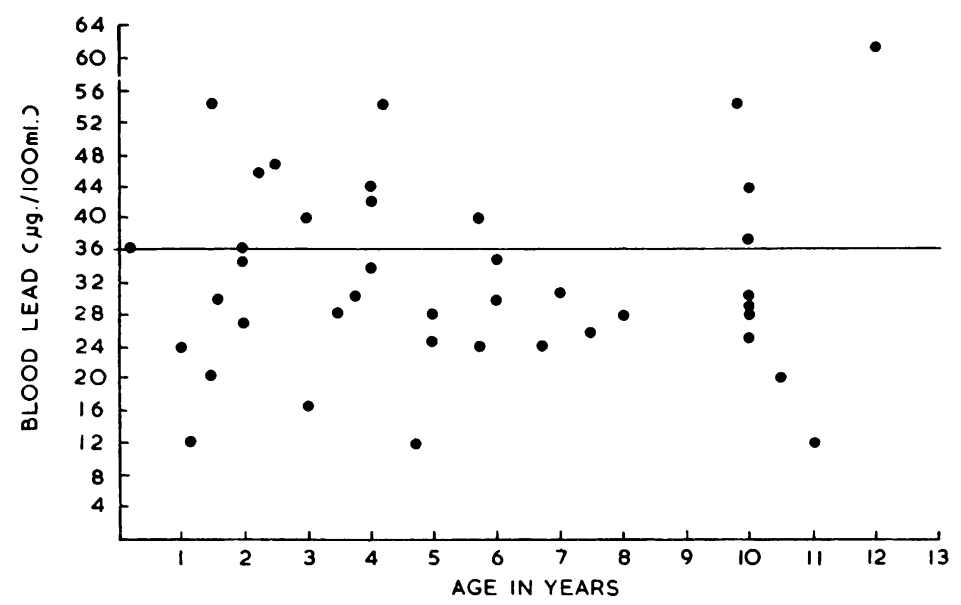

FIG. 3.-Levels of lead in the blood of children in whom the original diagnosis was 'encephalitis'. 
Levels in 'Encephalitis'. Blood lead was estimated in 40 children aged 2 months to 12 years in all of whom the consultant made a preliminary diagnosis (not necessarily confirmed subsequently) of 'encephalitis'. Results are shown in Fig. 3. Twelve (30\%) had levels greater than $36 \mu \mathrm{g} . / 100 \mathrm{ml}$. blood: Patient 6 in Table 1 is an example of this type.

Children with Severe Anaemia, Pica, Vomiting, etc. Blood lead was estimated in 52 patients with varying presenting symptoms such as abdominal pain, vomiting and general irritability; many of them had a history of pica or had a severe anaemia for which there was no apparent cause. In 28 $(54 \%)$ the lead level was higher than $36 \mu \mathrm{g} . / 100 \mathrm{ml}$.: Patients 4, 8, 10, 11, 13, 14, 15, 16 and 18 in Table 1 are examples of this type.

Levels of Pyruvate in Blood. The level of pyruvate in the blood was estimated after a dose of glucose (Payne-Poulton dosage, see Wilkinson, 1960), using the method of Friedemann and Haugen (1943). Results are given in Fig. 4 of tests on 36 children with levels of lead greater than $36 \mu \mathrm{g} . / 100 \mathrm{ml}$. blood. Abnormally high values (normal upper limit is $1.4 \mathrm{mg}$. $/ 100 \mathrm{ml}$. blood) were found in 20 of them. It will be apparent that though raised levels of lead can be associated with normal levels of pyruvate, lead levels of only 40 to $60 \mu \mathrm{g}$. may be associated with raised pyruvate levels, i.e. with evidence of an abnormality in the citric-acid cycle.

\section{Some Aspects of Lead Poisoning with Special Reference to 20 Patients}

In order to illustrate some of the difficulties encountered in diagnosis, and in some aspects of treatment, 20 patients with lead poisoning are described. This particular group is presented because they have been subjected to more intensive investigation. A summary of each patient is given in Table 1.

In the group there were 13 boys and seven girls. At the time of estimating blood lead their ages varied from 9 months to 5 years; 13 were Caucasian, two West Indian, two Indian, two the products of white mothers and West Indian fathers and one the product of a Greek father and an Italian mother. Patients 5 and 13 were brothers. Another brother, not included in this series, also had lead poisoning. Their father, a carpenter, was in the habit of bringing home putty containing red lead to do various jobs around the home. He, too, had a raised blood lead. Patients 6 and 7 were brother and sister, and 19 and 20 were brothers.

It is noteworthy that Patients 5 and 7 were discovered because it is customary to do blood lead estimations on siblings of diagnosed cases. In fact, Patients 5 and 7 , discovered by routine screening, were asymptomatic despite blood lead levels of 62 and $70 \mu \mathrm{g} . / 100 \mathrm{ml}$. respectively.

Eleven patients were direct referrals by the general practitioner to the hospital and lived locally. The

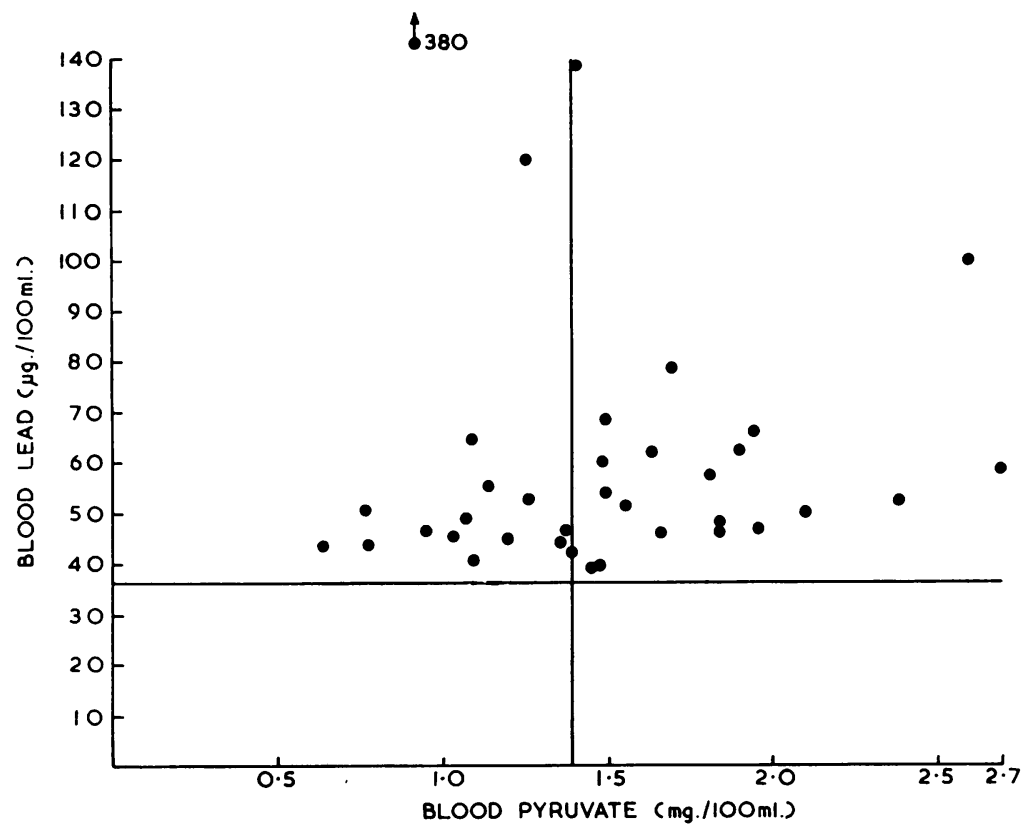

FIG. 4.-Levels of lead and pyruvate in the blood of some patients. 
remainder were referred from further afield by general practitioners or other paediatricians.

Twelve of the families lived in unfavourable conditions, i.e. old flats or tenement buildings, usually with unsatisfactory means of rubbish disposal and with the buildings in poor condition. Despite these poor conditions the children were generally well cared for. Only one child was the victim of overt neglect (Patient 1). His parents were separated and his care delegated to anyone who happened to be around. Five of the children were from excellent homes, both economically and socially.

Three of the children had had access to putty containing red lead and in the case of Patients 5 and 13 it was provided as a plaything. Four children had been eating old paint chippings in their homes. One child was known to eat paint peeling off outside railings and had been found sucking decorators' brushes loaded with paint for outdoor work. A further two were suspected of eating paint but this was not proven. Two siblings 'helped' their father to spray some cars. Two children, and their father, who also had a raised blood lead, received home-grown vegetables produced on a soil containing numerous lead battery casings from an old electricity generating plant; samples of cabbage contained up to $5 \cdot 3 \mathrm{mg}$. lead $/ \mathrm{kg}$. (normal $=0.10$ to $0 \cdot 25$, Kehoe, 1961). In all, five children had pica for dirt, coal and rubbish in general, but the actual source was never identified. Owing to language difficulties the source was unknown for Patient 18. Fifteen of the children had pica, but no child presented because of it. Often it was mentioned as an aside or had to be elicited by direct questioning. One mother categorically denied its presence and it was only confirmed when the child was admitted and he was observed to place in his mouth, or chew, any object in his vicinity.

Of these 20 children, one (Patient 3) was retarded and always had been, and one (Patient 2) was suspected of being psychotic or backward, or both, and presented because of deteriorating behaviour. Patient 9 presented because of regression of previously normal development, and the good and intelligent parents of Patients 19 and 20 considered their children were normal until after weaning. Though Patient 1 was admitted to hospital with vomiting and abdominal pain, blood lead was finally estimated because of his abnormal behaviour; similarly, Patient 12, though considered of normal intelligence, had become very irritable and difficult to handle. The others were considered to be of normal intelligence, though Patient 17 was thought to have a specific speech defect.
The presenting symptoms were varied and are indicated in Table 1 . Lead poisoning was diagnosed after varying intervals of time, and the estimation of blood lead was often one of the last investigations to be done.

Findings with respect to the time-honoured triad of punctate basophilia, coproporphyrinuria and the demonstration of lead in the gut or ends of the long bones in 18 of the patients in whom the data were complete are given in Table 2.

Aminoaciduria and glycosuria were not seen in any of the 20 patients, nor did any of them show 'lead lines' on the gum margins. Anaemia was a common finding, only five out of 18 children having a haemoglobin over $75 \%$. Morphologically the red cells were found to be various combinations of hypochromia, anisocytosis and polychromasia.

Particular attention is drawn to Patients 3 and 10 in whom the blood lead levels were only 48 and $40 \mu \mathrm{g} . / 100 \mathrm{ml}$. respectively.

TABLE 2

\begin{tabular}{|c|c|c|c|c|c|c|}
\hline & \multicolumn{5}{|c|}{ Blood Lead ( $\mu \mathrm{g} . / 100 \mathrm{ml})}$. & \multirow{2}{*}{ Total } \\
\hline & $40-50$ & $50-80$ & $80-110$ & 288 & 380 & \\
\hline $\begin{array}{l}\text { No. of patients } \\
\text { Punctate basophils } \\
\text { Coproporphyrinuria } \\
\text { Radiological evidence }\end{array}$ & $\begin{array}{l}2 \\
1 \\
0 \\
0\end{array}$ & $\begin{array}{r}11 \\
1 \\
0 \\
1\end{array}$ & $\begin{array}{l}3 \\
2 \\
1 \\
1\end{array}$ & $\begin{array}{l}1 \\
1 \\
0 \\
1\end{array}$ & $\begin{array}{l}1 \\
0 \\
1 \\
1\end{array}$ & $\begin{array}{r}18 \\
5 \\
2 \\
4\end{array}$ \\
\hline
\end{tabular}

Patient 3. A girl of 2 years and 8 months had always been slow to progress and was undoubtedly mentally retarded. She presented because for about three or four months she had ceased to make any progress at all and had become a little more difficult to manage. There were no other symptoms and her general health was good. A history of pica for dirt, especially coal, was elicited. Apart from being a hypotonic, retarded child, unable to walk at $2 \frac{1}{2}$ years, no other physical signs were discovered. Her haemoglobin was $90 \%$ and red cell morphology was normal. There was no excessive coproporphyrinuria or radiological evidence of increased lead ingestion. The level of lead was $48 \mu \mathrm{g}$./ $100 \mathrm{ml}$. blood and the blood pyruvate was $1.95 \mathrm{mg}$./ $100 \mathrm{ml}$. (upper limit of normal $1.4 \mathrm{mg} . / 100 \mathrm{ml}$.). In view of the raised blood lead, the raised pyruvate and the clinical history it was decided to treat her with penicillamine $150 \mathrm{mg}$. b.i.d. by mouth. Within a month the mother reported unequivocal improvement in her behaviour and demeanour. She became easier to handle, more alert and much more interested in her surroundings. Mother insisted that her progress was speeding up. After two weeks' treatment her pyruvate level had fallen to $0.72 \mathrm{mg} . / 100 \mathrm{ml}$. blood. Penicillamine was continued for about three months by which time the blood lead had fallen to $29 \mu \mathrm{g} . / 100 \mathrm{ml}$. No sideeffects were noted. No proteinuria was discovered. 
TABLE 3

PSYCHOLOGIST'S REPORT ON PATIENT 3

\begin{tabular}{|c|c|c|c|c|}
\hline Date of Assessment & Age (yrs.) & Mental Age Score & D.Q. or I.Q. Score & Test Used and Comments \\
\hline 25.10 .61 & $2 \frac{9}{12}$ & $\begin{array}{l}12 \mathrm{mths} \text {. } \\
\text { approximately }\end{array}$ & $\begin{array}{l}\text { I.Q. } \\
\text { approximately }\end{array}$ & Griffiths' scale; child noted to be lethargic \\
\hline 30.6 .62 & & & & Commenced penicillamine \\
\hline 24.7 .62 & $3 \frac{6}{12}$ & $\begin{array}{l}18 \mathrm{mths} \text {. } \\
\text { approximately }\end{array}$ & D.Q. 43 & $\begin{array}{l}\text { Griffiths' scale; co-operation poor; doubtful } \\
\text { educability }\end{array}$ \\
\hline
\end{tabular}

She was seen by Mr. L. Gardner, psychologist, whose reports are summarized in Table 3.

Mr. Gardner continues: 'The increase in her quotient of 13 points (from 43 to 56 ) is encouraging, and although the results on different tests are being compared, the Griffiths and Binet scales have much in common and their standard deviations are not markedly different at this age level. It was noted that the increase in her test scores might be attributed to her increased co-operation, but in the psychologist's opinion this factor of co-operation was not the main feature and it seems likely, as far as one can tell, that her rate of intellectual development has increased.'

Patient 10. A girl who did well until the age of 6 months when she weighed $24 \mathrm{lb}$. $(10.9 \mathrm{~kg}$.); subsequently failed to thrive and lost weight, though her appetite was good and her bowels were considered normal. Her weight on admission at the age of 1 year and 9 months was only $18 \mathrm{lb} .14 \mathrm{oz}$. $(8.5 \mathrm{~kg}$.). She tried to walk but had been making no progress. At 1 year of age she had had some episodes when she shook her head violently and rolled her eyes.

After extensive investigations the only positive findings were (1) a haemoglobin of $66 \%$, (2) a blood film showing hypochromia, polychromasia and slight punctate basophilia, (3) high blood pyruvate of $2.71 \mathrm{mg} . / 100 \mathrm{ml}$., (4) blood lead of $40 \mu \mathrm{g} . / 100 \mathrm{ml}$., i.e. only just above the upper limit of normal. Her father was a spray painter and the housing was poor.

It was decided to treat this child for lead poisoning with penicillamine. Within eight days she was more active and walking readily with support. When discharged after three months her weight was $24 \mathrm{lb}$. $(10.9 \mathrm{~kg}$.), her haemoglobin had risen to $77 \%$, there was no punctate basophilia and she was walking well though her gait was not completely normal. Ten days after commencing treatment her blood lead rose to $60 \mu \mathrm{g}$./ $100 \mathrm{ml}$., but had fallen to $38 \mu \mathrm{g}$. by the time of discharge; the pyruvate level had fallen to $1.47 \mathrm{mg}$. $/ 100 \mathrm{ml}$. blood on the nineteenth day of treatment.

\section{Treatment}

All patients in Table 1 were at some time or other treated with oral penicillamine $(150 \mathrm{mg}$. b.i.d., $300 \mathrm{mg}$. b.i.d., $450 \mathrm{mg}$. b.i.d. for children aged up to
5 years, 5-10 years and over 10 years, respectively). Four patients in addition received one or two courses of intramuscular calcium disodium ethylenediamine tetra acetic acid (EDTA) and one received two courses of intravenous EDTA. The dose of EDTA was $75 \mathrm{mg}$. per $\mathrm{kg}$. body weight per day, and for intramuscular use it was made up in $20 \%$ solution with $5 \%$ procaine and given in divided doses (the oral use of EDTA is contraindicated because it may increase the absorption of lead and precipitate an encephalopathy with fatal results (Byers, 1959)).

Urine was collected from five patients for the estimation of lead output under different régimes. The course of the blood lead and where possible, pyruvate levels, were followed also.

The result of treating only with oral penicillamine is illustrated by Patient 13 (first admission) and shown in Fig. 5 and Table 4.

Patient 13. Before treatment his urinary output of lead was within normal limits. With penicillamine there was approximately a fivefold increase of the total output per day. After 32 days of treatment his daily output of lead began to fall, and his blood lead, originally $68 \mu \mathrm{g} . / 100 \mathrm{ml}$., had fallen to $40 \mu \mathrm{g} . / 100 \mathrm{ml}$. It is noteworthy that his pyruvate level, originally above normal, rose in the early stages of treatment and then after about 30 days came down to the upper limit of normal. Clinically he was much improved and was discharged.

Unfortunately, in spite of vigorous efforts to rid his home of the red lead that was the source in his case, he was seen in the out-patients' department at a later date and found to have a blood lead of $85 \mu \mathrm{g} . / 100 \mathrm{ml}$. $\mathrm{He}$ was accordingly readmitted and given a five-day course of intramuscular EDTA. The urinary excretion of lead during this period is recorded in Table 4.

The use of intramuscular EDTA is illustrated by Patients $11,5,13$ and 18 who were given five-day courses. The results are shown in Table 4, and Fig. 7 illustrates the response of Patient 18.

Patient 11, with an initial blood lead of $388 \mu \mathrm{g}$./ $100 \mathrm{ml}$., produced the highest concentration of lead in the urine, i.e. $1,700 \mu \mathrm{g} . / \mathrm{l}$, , and on the whole it 
TABLE 4

EFFECT OF CHELATING AGENTS IN FOUR PATIENTS

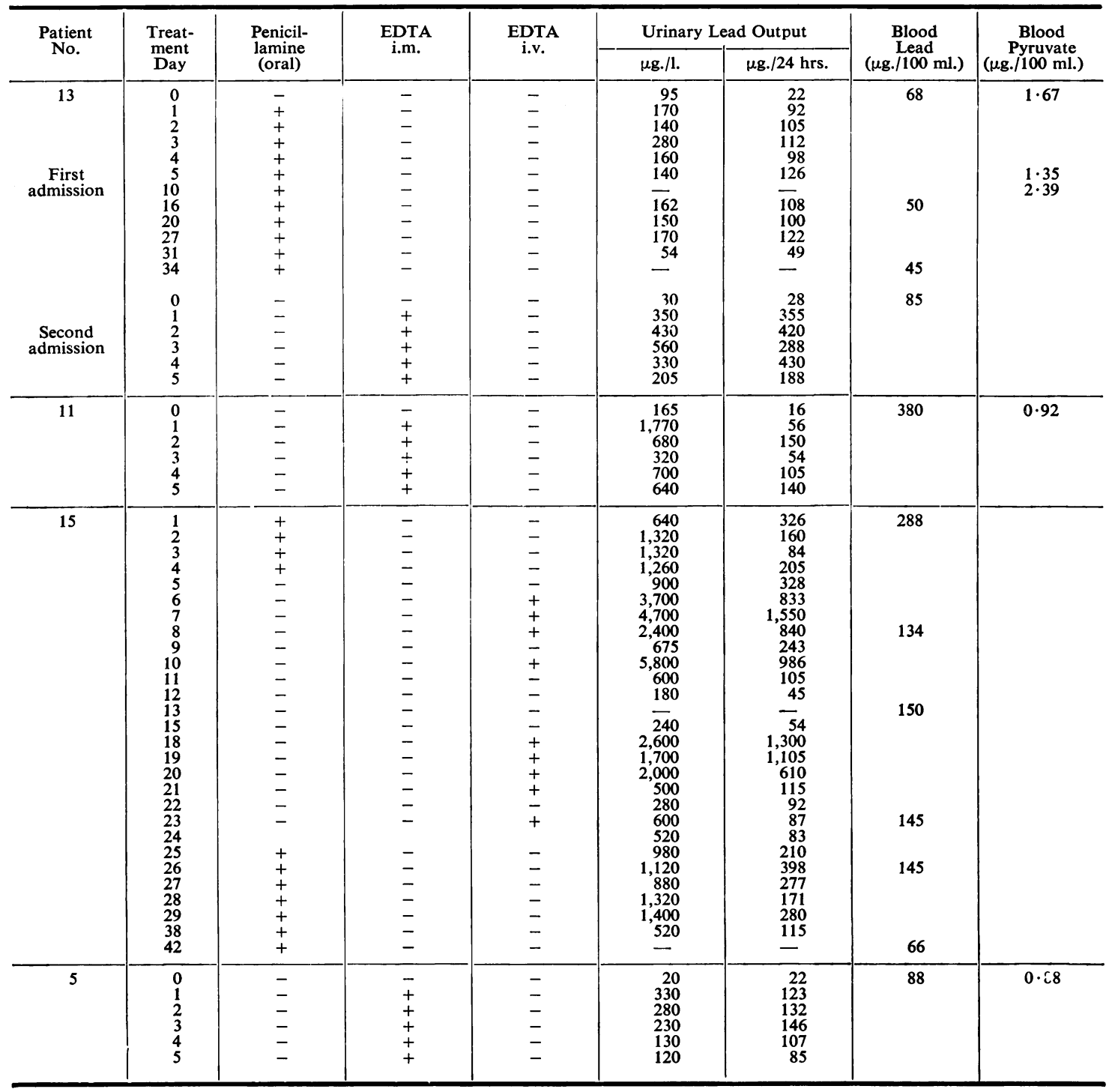

appears that EDTA is able to remove more lead than penicillamine over a period of five days. In interpreting the figures due regard must be paid to the fact that the children varied in their sizes, fluid input and urinary output; these factors are important when considering the lead output in absolute values.
Treatment was commenced with oral penicillamine for four days followed by intravenous EDTA. The results are shown in Fig. 6 and Table 4. Intravenous EDTA considerably increased the excretion of lead and far exceeded the ability of penicillamine to do so in this case.

No side-effects, in particular proteinuria, were 

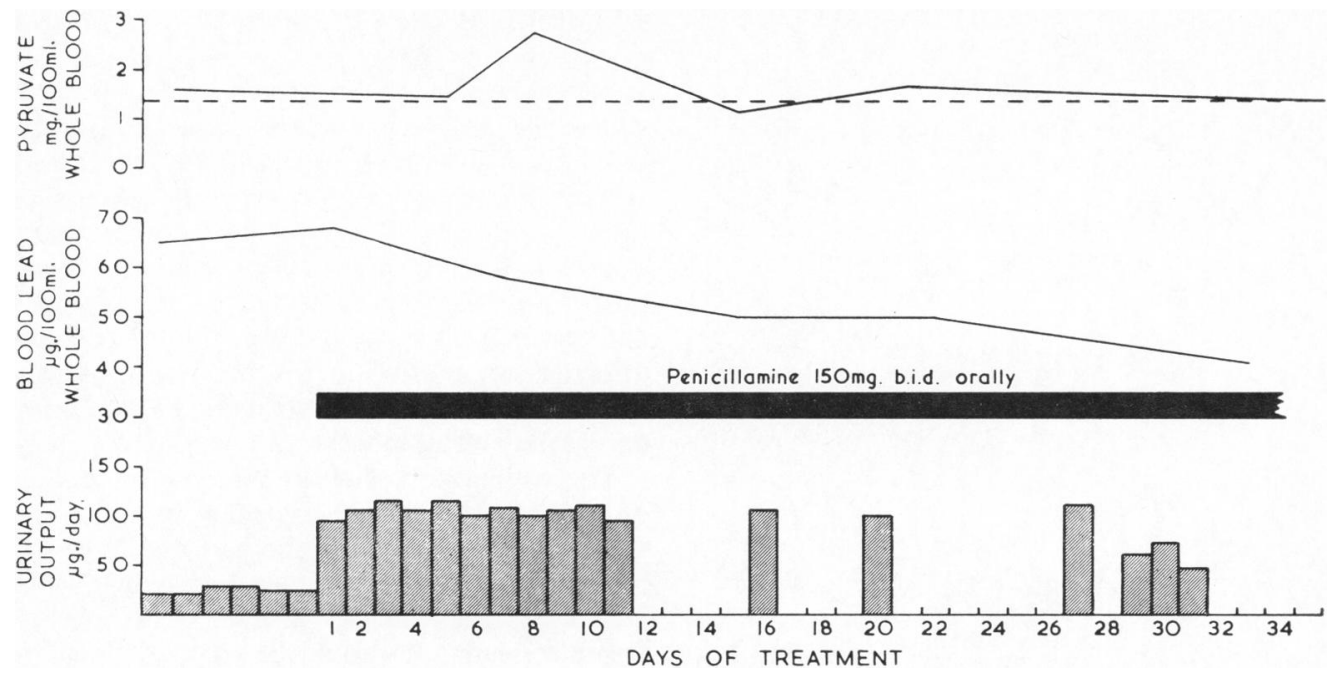

Fig. 5.-Effect of treatment in Patient 13.

Discussion

During the 10-year period 1951 to 1960 , the records of The Hospital for Sick Children show that 12 children were diagnosed as suffering from lead poisoning, that is about one patient a year.

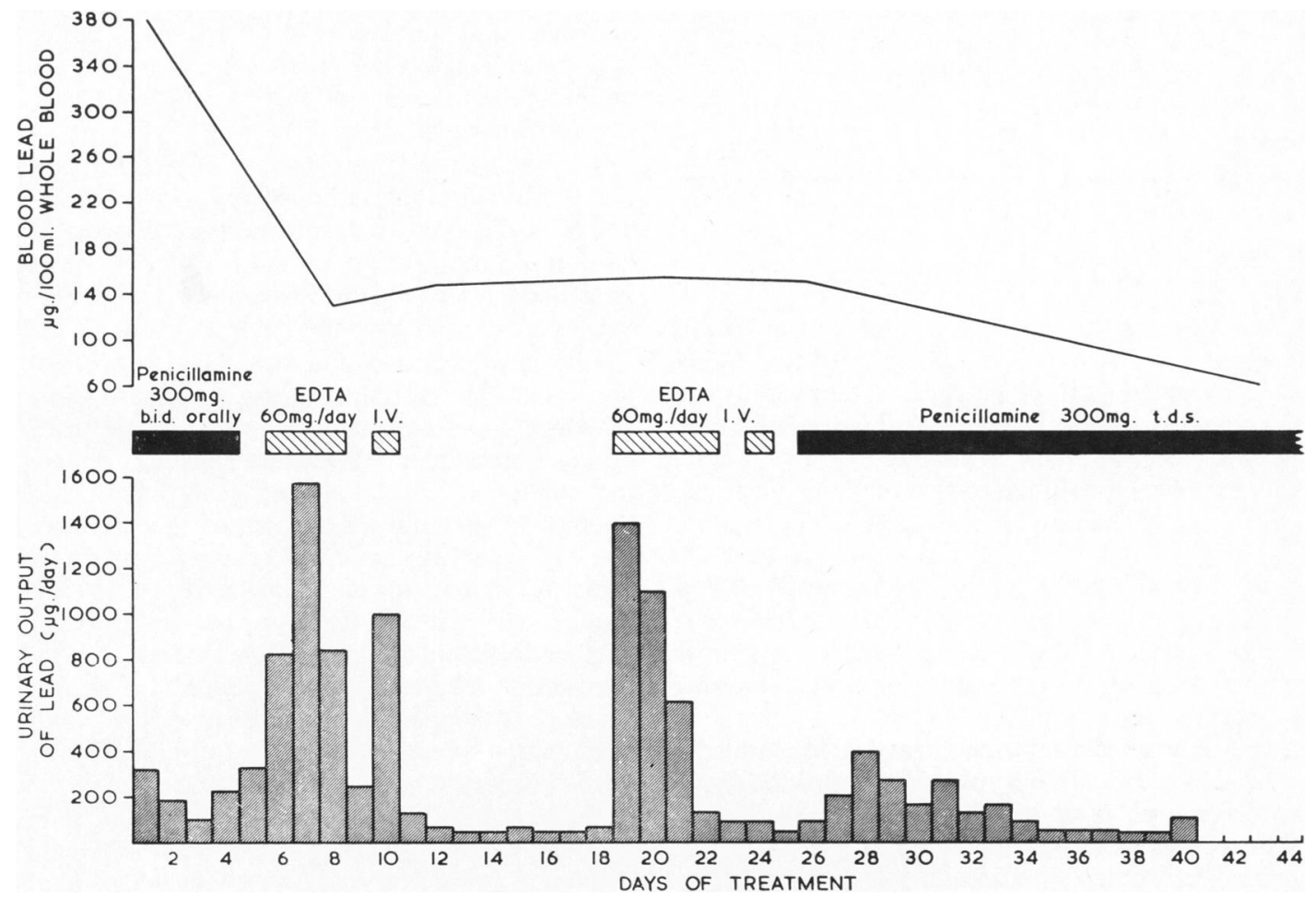

From the data now presented on children with mental retardation, 'encephalitis', severe anaemia, failure to thrive, abdominal pain, etc., it is apparent that the incidence of diagnosed cases has risen enormously since January 1961, when the estimation

Fig. 6.-Effect of treatment in Patient 15. 


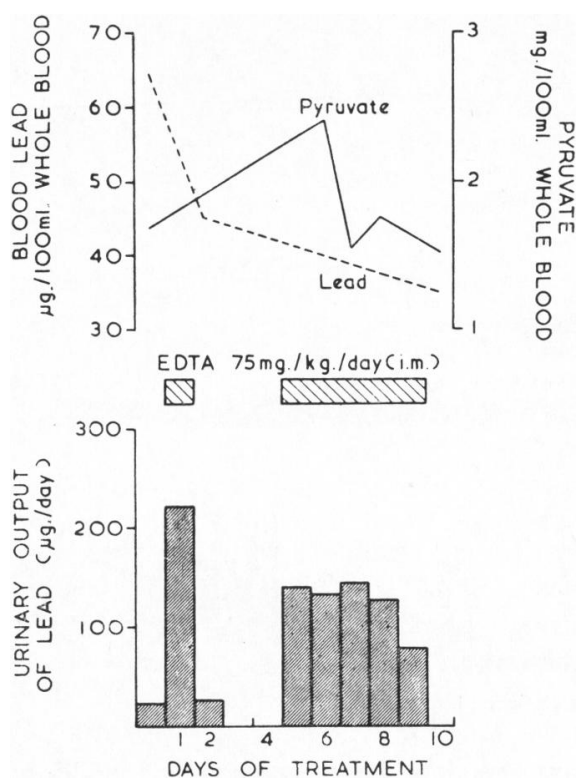

Fig. 7.-Effect of treatment in Patient 18.

of blood lead became freely available, and the laboratory staff continuously urged the resident medical staff to make use of the service. From January 1961 to May 1963 (i.e. two years and four months), the following numbers of patients had blood leads greater than the levels seen in normal children.

\begin{tabular}{lr|c|c|c|c|c}
\hline Blood lead ( $\mu \mathrm{g} . / 100 \mathrm{ml})$. &.. & $40-50$ & $50-60$ & $60-70$ & $70-80$ & $>80$ \\
Number of children &.. & 42 & 17 & 12 & 3 & 5 \\
\hline
\end{tabular}

Even if the classical upper level of normal is accepted, i.e. 50 to $60 \mu \mathrm{g} . / 100 \mathrm{ml}$. (Byers, 1959), it is apparent that the incidence of diagnosed lead poisoning has risen since the estimation of blood lead became more freely available.

Our experience is similar to that of many American workers (e.g. Mellins and Jenkins, 1955; McLaughlin, 1956). McLaughlin (1956) drew attention to the fact that the number of cases reported to the Board of Health of New York City increased from one in 1950 to 80 in 1954 following publicity and more accurate criteria for diagnosis, particularly the estimation of blood lead levels.

The diagnosis of established, classical lead poisoning usually presents no problem, particularly if there is a high level of awareness and suspicion, if a history of pica is elicited and a source of lead is found. Before this situation develops, lead poisoning may mimic so many diseases that the diagnosis is difficult. It may be initially asymptomatic or present as a vague non-specific illness. It may assume the guise of an obscure refractory anaemia simulating an iron-deficiency state and there may in fact be a simultaneous iron deficiency. Anorexia, vomiting or abdominal pain may be the predominating symptoms. Consequently the patient may originally attend for a surgical opinion. Symptoms related to the central nervous system may be subtle and show up as generalized irritability, a behaviour disorder or a slowing up or even regression of intellectual progress. Involvement of the peripheral nerves may result in weakness or a frank paralysis.

The emphasis placed on the time-honoured triad of punctate basophilia, coproporphyrinuria and the demonstration of lead in the gut or ends of the long bones can easily result in cases being overlooked. Their presence can, of course, point an accusing finger at lead. It should be realized that all three may be entirely absent in established lead poisoning so that their absence does not exclude this diagnosis. Also, the presence of punctate basophilia and coproporphyrinuria does not invariably incriminate lead. Punctate basophilia may accompany any severe refractory anaemia, and coproporphyrinuria may occur occasionally in other diseases such as rheumatic fever, poliomyelitis, iron deficiency anaemia and cirrhosis of the liver. Similarly, aminoaciduria and glycosuria were absent in all our patients, nor did any of them have 'lead lines' on the gum margins.

The value of eliciting a history of pica as a routine case finding method is illustrated in our series and confirms the work of Jacobziner and Raybin (1962) who found that $24 \%$ of children with pica had lead poisoning. Also in our experience the finding of anaemia was very helpful (Table 1).

Ultimate diagnosis and the decision to treat or not to treat the 'borderline' case is extremely difficult and depends on consideration of the whole problem, taking into account the clinical findings as well as the results of the laboratory tests. In a further attempt to sort out this aspect of the problem the level of pyruvate in the blood was estimated in some of our patients as shown in Fig. 4, since thiol groups essential for the pyruvate oxidase system may be inhibited by lead. The finding of a raised pyruvate level has been considered to be further evidence in support of a diagnosis of lead toxicity, particularly when the increase of blood lead has been 'borderline'. The converse, however, is not true since blood lead can be very high and the pyruvate level normal: it is possible that severe poisoning interferes with intermediary metabolism before the stage of pyruvate oxidation. 
After establishing the range of values for blood lead in normal children, it was shown that the levels were frequently higher in an unselected series of mentally retarded children and those with behaviour disorders than in others. It is suggested that the ingestion of lead may lead to further deterioration in a child who is mentally retarded from other causes, and Patient 3, Table 1, demonstrates how improvement may follow the administration of a chelating agent to such a child even though the level of lead was only $48 \mu \mathrm{g} . / 100 \mathrm{ml}$. blood. It would be of great interest to treat a series of mentally retarded children with blood leads between 40 and $60 \mu \mathrm{g} . / 100 \mathrm{ml}$. as even small improvements can make a great difference to the family as a whole.

The data also show that a change in behaviour may be associated with lead toxicity. This aspect has been reviewed by White and Fowler (1960), and when a child has become irritable, withdrawn, nervous, disobedient or has crying spells, lead poisoning should always be considered. So far, the estimation of lead in the blood is the only certain way of demonstrating excessive exposure to lead.

It is known that the requirement of the brain for oxygen is considerably higher in infants and young children up to 4 years of age than in older people (Kennedy, 1956). The citric acid cycle is of particular importance in the metabolism of the brain, and inhibition of the pyruvate and other oxidative systems will seriously interfere with the energy supply to the brain cells (Peters, 1953). This toxic effect of lead may be of greater importance in the metabolism of the brain in children than in adults.

Lead is mainly held by the red blood cells (Blumberg and Scott, 1935; Bambach, Kehoe and Logan, 1942; Hevesy, 1952). Bambach et al. (1942) have presented evidence suggesting that a rapid reaction takes place between lead and a specific constituent in the cells. Subsequently, Reddi (1953) showed that this constituent consisted of a protein and probably a phenolic compound. The percentage of lead in the plasma increases during therapy with edathamil calcium-disodium (Bessman and Layne, 1955), and the metabolism of chelated lead is very different from that of lead alone. It is proposed to make a study of the binding of lead in young children compared with adults.

The treatment of lead poisoning consists of five separate but equally important measures.

(1) The removal of the child from the source of lead, usually by placement in hospital for treatment.

(2) The removal of lead from the gastro-intestinal tract. Lead persists in the bowel for a considerable time unless active measures are undertaken to assist its elimination. This is frequently done by mild enemata and is probably a wise routine procedure and should not depend on whether radio-opaque material is visible on an x-ray film, because if the lead is finely divided it may not be seen.

(3) Removal of lead from blood and tissues by means of the chemical chelating agents.

(4) A thorough search for lead in the home and environment of the child, usually with the assistance of the local Health Authority. Medical recommendations for rehousing suitable families are fully justifiable.

(5) There is evidence to suggest that pica in some children has psychological implications and may be symptomatic of an underlying emotional disturbance (Mellins and Jenkins, 1955; Millican, Lourie and Layman, 1956). This being so, psychiatric advice and guidance should be sought if the treatment is to be complete. Pica is a notoriously difficult symptom to treat and recurrence rates of re-intoxication are high if the measures set out in (4) are not rigorously applied.

The two chelating agents in commonest use at present are as follows:

(1) calcium disodium ethylenediamine tetra acetic acid, $\mathrm{CaNa}_{2}$ EDTA.

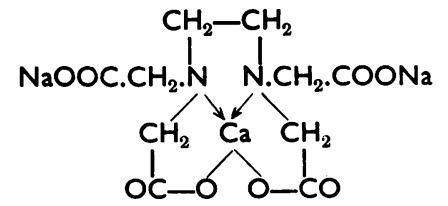

The mechanism of chelating is by substitution of the calcium by the lead.

(2) Penicillamine ( $\beta \beta$-dimethylcysteine). This was introduced by Walshe (1956) for the treatment of Wilson's disease, and subsequently of lead poisoning (Ohlsson, 1962; Goldberg, Smith and Lochhead, 1963).<smiles>CC(C)(S)C(N)C(=O)O</smiles>

Chelation depends on the affinity of the lead for the sulphydryl group - $\mathrm{SH}$.

In addition to chelating lead, penicillamine may be of value in supplying thiol groups (Clayton and Patrick, 1961).

From the studies described it can be concluded that penicillamine produces an effective rise in urinary lead excretion, which over the same period of time compares favourably with intramuscular EDTA. It has the great advantage of oral administration, can be used continuously and appears to be an adequate treatment for milder cases of lead 
toxicity. Since intravenous EDTA produces the maximum excretion rates, its use is indicated in severe poisoning (Byers and Maloof, 1954).

No evidence of renal damage was observed in our series of treated patients. Proteinuria has been reported after excessive doses of EDTA (Foreman, Finnegan and Lushbaugh, 1956), and there are reports of two instances of proteinuria following penicillamine. Fellers and Shahidi (1959) observed the onset of a nephrotic syndrome in a 16-year-old boy after penicillamine, and Goldberg et al. (1963) found proteinuria in a 38-year-old man with lead poisoning, after four months' treatment. It is Walshe's experience (1962) that penicillamine is particularly non-toxic and after very extensive experience he has not seen renal damage.

The provision of a satisfactory service for estimating the level of lead in blood is an essential requirement for the paediatrician. The clinician must always be aware that lead poisoning can present in bizarre ways in children, and he should do his best to detect and treat lead toxicity before the onset of very severe symptoms. The diagnosis should always be considered when there is a history of pica, changes in behaviour or unexplained anaemia. Due consideration should be given to the fact that a child may have mild lead poisoning on top of mental retardation due to other causes. Preconceived ideas about the level of blood lead at which toxicity occurs should be abandoned; levels of lead in blood between 40 and $60 \mu \mathrm{g}$. $/ 100 \mathrm{ml}$. should be carefully considered in the light of other clinical findings, particularly when the child is under 5 years of age.

We should like to thank the Physicians at The Hospital for Sick Children for giving us the opportunity of investigating their patients. Much valuable technical assistance has been given by Mr. P. Jenkins, Mrs. A. Warren and Miss P. Vinter. The help of the Nursing Staff is gratefully acknowledged. Financial assistance has been given by the Nuffield Foundation and the Joint Research Board of The Hospital for Sick Children and the Institute of Child Health, and for this we are most grateful. Dr. F. E. Camps kindly provided some accommodation at the Harben Laboratories of the Royal Institute of Public Health and Hygiene during part of these investigations.

\section{REFERENCES}

Analytical Methods Committee (1959). The determination of lead. Analyst, 84, 127.

Bambach, K., Kehoe, R. A. and Logan, M. A. (1942). The plasmacell partition of blood lead. J. Pharmacol. exp. Ther., 76, 326.

Bessman, S. P. and Layne, E. C. (1955). Distribution of lead in blood as effected by edathamil calcium-disodium. A.M.A. Amer. J. Dis. Child., 89, 292.
blood as effected by

Blumberg, H. and Scott, T. F. McNair (1935). The plasma-cell partition of blood lead in clinical lead poisoning. Bull. Johns Hopk. Hosp., 56, 311.

Bradley, J. E., Powell, A. E., Niermann, W., McGrady, K. R. and Kaplan, E.. (1956). The incidence of abnormal blood levels of lead in a metropolitan pediatric clinic. J. Pediat., 49, 1.
Byers, R. K. (1959). Lead poisoning. Review of the literature and report on 45 cases. Pediatrics, 23, 585.

and Lord, E. E. (1943). Late effects of lead poisoning on mental development. Amer. J. Dis. Child., 66, 471 . and Maloof, C. (1954). Edathamil calcium-disodium (versenate) in treatment of lead poisoning in children. A.M.A.J. Dis. Child., 87, 559.

Chisolm, J. J., Jr. and Harrison, H. E. (1957). The treatment of acute lead encephalopathy in children. Pediatrics, 19, 2.

Clark, N. S. (1950). Lead poisoning in infancy. Arch. Dis. Childh. 25, 297.

Clayton, B. E. and Patrick, A. D. (1961). Use of dimercaprol or penicillamine in the treatment of cystinosis. Lancet, 2, 909.

Fellers, F. X. and Shahidi, N. T. (1959). The nephrotic syndrome induced by penicillamine therapy. A.M.A. J. Dis. Child., $98,669$.

Foreman, H., Finnegan, C. and Lushbaugh, C. C. (1956). Nephrotoxic hazard from uncontrolled edathamil calcium-disodium therapy. J. Amer. med. Ass., 160, 1042.

Friedemann, T. E. and Haugen, G. E. (1943). Pyruvic acid. II. The determination of keto acids in blood and urine. J. biol. Chem., 147, 415.

Goldberg, A., Smith, J. A. and Lochhead, A. C. (1963). Treatment of lead-poisoning with oral penicillamine. Brit. med. J., 1, 1270.

Hevesy, G. de (1952). Application of radioactive indicators in vascular studies. Advanc. Sci., 9, 57

Jacobziner, $H$. and Raybin, $H$. W. (1962). The epidemiology of lead poisoning in children. Arch. Pediat. . 79, 72

Kehoe, R. A. (1961). The metabolism of lead in man in health and disease. I. The normal metabolism of lead. J. roy. Inst. publ. Hlth, 24, 81 .

Kennedy, C. (1956). The cerebral metabolic rate in children. In Neurochemistry, ed. S. R. Korey and J. I. Nurnberger, p. 230 [Progress in Neurobiology. I]. Hoeber, New York.

McLaughlin, M. C. (1956). Lead poisoning in children in New York City, 1950-1954; an epidemiologic study. N.Y. St. J. Med. 56, 3711 .

Mellins, R. B. and Jenkins, C. D. (1955). Epidemiological and psychological study of lead poisoning in children. J. Amer. med. Ass., 158, 15.

Millican, F. K., Lourie, R. S. and Layman, E. M. (1956). Emotional factors in the etiology and treatment of lead poisoning. A.M.A. Amer. J. Dis. Child., 91, 144.

Ohlsson, W. T. L. (1962). Penicillamine as lead-chelating substance in man. Brit. med. J., 1, 1454.

Peters, R. (1953). Significance of biochemical lesions in the pyruvate oxidase system. Brit. med. Bull., 9, 116.

Reddi, K. K. (1953). Isolation of thorium B (lead)-binding substance from the erythrocytes of rabbit blood. Nature (Lond.), 172, 202.

Walshe, J. M. (1956). Penicillamine, a new oral therapy for Wilson's disease. Amer. J. Med., 21, 487.

(1962). Penicillamine and nephrotoxicity. Brit. med. J., 1,1009 .

White, H. H. and Fowler, F. D. (1960). Chronic lead encephalopathy. A diagnostic consideration in mental retardation. Pediatrics, 25, 309

Wilkinson, R. H. (1960). Chemical Micromethods in Clinical Medicine. Charles C. Thomas, Springfield, Illinois.

\section{Appendix}

\section{Estimation of Lead in Blood and Urine}

A modification of the method developed by the Department of Industrial Medicine (Medical Research Council) was employed. Blood or urine was digested with an acid mixture, taking special care to avoid contamination (Analytical Methods Committee, 1959). The resulting lead salt was dissolved in an alkaline cyanide-citrate solution to which was added an excess of dithizone. The latter reacted with lead by chelation to form a pink complex which was stable in the presence of cyanide at $p \mathrm{H} 8 \cdot 4$.

To reduce the risk of contamination, venous samples of blood were taken into disposable plastic syringes using heparin from a fresh ampoule. The needle of the syringe was bent at a right angle and plunged into a cork; the blood was then stored in the syringe in the refrigerator until the estimation was begun. 
Reagents

(1) Sulphuric acid: concentrated

(2) Perchloric acid: weight per $\mathrm{ml}$. $=1.53 \mathrm{~g}$.

(3) Nitric acid: specific gravity $1 \cdot 42$

(4) Ammonia: specific gravity 0.880

(5) Citric acid: Analar

(6) Potassium cyanide

(7) Chloroform: Analar: redistilled from calcium hydroxide.

(8) Dithizone: $0 \cdot 1 \%$ solution in chloroform kept under sulphurous acid at $4^{\circ} \mathrm{C}$.

(9) Ammonium citrate $50 \%$. 500 g. citric acid were dissolved in $300 \mathrm{ml}$. distilled water; $450 \mathrm{ml}$. ammonia were added carefully with stirring and cooling. Three drops phenol red were added and additional ammonia until $p H$ was 8.5 (i.e. indicator turned from yellow to pink). The solution was placed in a separating funnel, $10 \mathrm{ml}$.

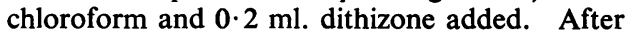
shaking and allowing to separate, the chloroform layer was removed. The ammonium citrate solution was washed with chloroform three times using $45 \mathrm{ml}$. in all. The final separation was performed after letting the mixture stand overnight. This solution was stored indefinitely.

(10) Potassium cyanide: $10 \%(w / v)$ solution in water. This was made up fresh each month.

(11) Cyanide/citrate/ammonia solution: $30 \mathrm{ml}$. $10 \%$ cyanide solution, $3 \mathrm{ml}$. $50 \%$ ammonium citrate, and $10 \mathrm{ml}$. ammonia were made up to 1 litre with distilled water. This solution was stored indefinitely.

(12) Cyanide/ammonia wash solution: this was made up fresh each time. $10 \mathrm{ml} .10 \%$ potassium cyanide solution and $10 \mathrm{ml}$. ammonia were made up to 1 litre with distilled water.

(13) Standard lead solution: $183.1 \mathrm{mg}$. lead acetate $\left(\left(\mathrm{CH}_{3} \mathrm{COO}\right)_{2} \quad \mathrm{~Pb} 3 \mathrm{H}_{2} \mathrm{O}\right)$ were dissolved in distilled water, $3 \mathrm{ml}$, , redistilled acetic acid added and the solution made up to 1 litre with distilled water. This solution was kept indefinitely.

Glassware. All reagents were stored in borosilicate glass or polythene bottles.

All glassware used for making up solutions and for the determinations was washed in detergent and distilled water, placed in $3 \%(\mathrm{v} / \mathrm{v})$ nitric acid for about 16 hours, rinsed in three changes of distilled water, and dried in an oven, making sure no metal touched the glass. It was stored under cover to prevent dust settling on it, and kept for lead determinations only. All new beakers and tubes had to be submitted to the digestion procedure before use in order to avoid erroneously high results. (Dichromate solution cannot be used for washing glassware as lead chromate is insoluble.)

\section{Procedure}

URINE. 24-hour collection of urine was well shaken and measured. To $100 \mathrm{ml}$. urine in a $250 \mathrm{ml}$. beaker,
$25 \mathrm{ml}$. nitric acid and $10 \mathrm{ml}$. perchloric acid were added and the mixture boiled to dryness in a sand-bath (4-5 hrs.). The sample was not left to 'bake' as this gave losses up to $50 \%$. A white crystalline residue was required; if it was brown a few drops of nitric acid were added and the mixture reboiled; if the colour persisted, a few drops of perchloric acid were added and the mixture boiled to dryness.

When the sample had stopped fuming it was dissolved in distilled water with slight warming, and the solution transferred to a $250 \mathrm{ml}$. separating funnel with two washings of water. $5 \mathrm{ml}$. ammonia, $3 \mathrm{ml}$. $50 \%$ ammonium citrate and $10 \mathrm{ml}$. cyanide/citrate/ammonia solution were added with swirling to mix the contents and then $0.2 \mathrm{ml}$. $0 \cdot 1 \%$ dithizone followed by $20 \mathrm{ml}$. chloroform. After shaking for 30 seconds and allowing to separate, the chloroform layer was run on to a $Q$-and-Q stoppered tube $(50 \mathrm{ml}$.) and washed with four successive $20 \mathrm{ml}$. portions of the cyanide/ammonia solution, the aqueous layer being removed each time with a filter pump. A roll of $9 \mathrm{~cm}$. Whatman's No. 42 filter paper was dropped into the chloroform to remove the last traces of water, and the colour was measured at $525 \mathrm{~m} \mu$ against a water blank.

If the patient was receiving a chelating agent, $25 \mathrm{ml}$. urine was often a sufficient sample and in this case $20 \mathrm{ml}$. nitric acid and $5 \mathrm{ml}$. perchloric acid were used.

BLOOD. Using a pipette calibrated to contain, $3 \mathrm{ml}$. blood were placed in a $\mathrm{Q}$-and-Q stoppered tube $(50 \mathrm{ml}$.) and the pipette washed out with $2 \mathrm{ml}$. water. $5 \mathrm{ml}$. nitric acid, $3 \mathrm{ml}$. perchloric acid and $0.5 \mathrm{ml}$. sulphuric acid were added, the tube swirled to mix, and then stood for 30 minutes to prevent excess frothing on heating. The tube was boiled in a sand-bath until only the sulphuric acid was left (about 90-120 minutes), and then heated over a Bunsen until all fuming ceased. After cooling, $3 \mathrm{ml} .50 \%$ ammonium citrate, $5 \mathrm{ml}$. ammonia and $10 \mathrm{ml}$. cyanide/citrate/ammonia solution were added, the tube swirled to mix, and $0.1 \mathrm{ml}$. $0.1 \%$ dithizone followed by $10 \mathrm{ml}$. chloroform added. The tube was stoppered, shaken for 30 seconds and allowed to settle. The aqueous layer was removed with a filter pump and the chloroform washed with four portions of $20 \mathrm{ml}$. cyanide/ ammonia solution. During the washes the chloroform layer changed from green to pink and the last wash was not brown. A roll of $9 \mathrm{~cm}$. Whatman's No. 42 filter paper was dropped in the tube, and the solution read at $525 \mathrm{~m} \mu$ against a water blank.

Calibration Graph. $10-50 \mu \mathrm{g}$. lead/10 ml. or $20 \mathrm{ml}$. chloroform (depending on whether the calibration was for urine or blood) were extracted and a calibration curve constructed.

Accuracy of the Method. Duplicate estimations agreed within $4 \cdot 5 \%( \pm 3 \cdot 9$ S.D. $)$.

With each batch of estimations, a sample of blood with and without added lead was subjected to the entire procedure. The mean recovery was $89 \% \pm$ S.D. $4 \cdot 7$. 